\title{
Textural patterns, mineralogy, and chemistry of sandstone-related Calçadinha chalcedony (Piauí, Brazil)
}

\author{
Aspectos texturais, mineralógicos e químicos das calcedônias \\ Calçadinha alojadas em arenitos (Piauí, Brasil)
}

\section{Marcondes Lima da Costa ${ }^{1^{*}}$, Quézia da Silva Alencar ${ }^{2}$, Erico Rodrigues Gomes ${ }^{3}$, Henrique Diniz Faria de Almeida ${ }^{4}$, Sarise Kamanda de Oliveira ${ }^{3}$}

\begin{abstract}
Paleozoic sandstones of the Parnaíba Basin, in addition to hosting opal deposits, also have occurrences of chalcedonies with potential for mineral and ornamental handicrafts, in addition to assisting the understanding of the geological evolution of the basin. However, the chalcedonies were not investigated yet, and this study intended to fulfill this gap by the investigation of the chalcedonies of Calçadinha in Piauí. Fieldwork, microtexturals analysis, X-ray diffraction and scanning electron microscopy with energy dispersive spectrometry, chemical analysis, and gemological assessments were developed. Four distinct types of chalcedonies have been distinguished. They stand out for their well distribution of $\mathrm{Fe}$ and $\mathrm{Mn}$ dendrites, which involves opal nodules, and contains microcavities with well-formed microcrystalline quartz, nontronite, and palygorskite. The mesoscopic features of these chalcedonies and cabochon and free forms cutting show potential for use in mineral crafts and semi-jewels. As expected, the chalcedonies are dominated by high contents of $\mathrm{SiO}_{2}$, besides the low and variable contents of $\mathrm{Al}_{2} \mathrm{O}_{3}$, $\mathrm{Fe}_{2} \mathrm{O}_{3}, \mathrm{MgO}$, and $\mathrm{TiO}_{2}$. Among trace elements that show high Ba contents, bound in barite, seem also to be a geochemical signature of the country sandstones in Parnaíba basin. These chalcedonies were formed during the partial solubilization of $\mathrm{SiO}_{2}$ of sandstones, which was promoted during their tectonic formation in faults and fractures zones.
\end{abstract}

KEYWORDS: Manganese dendrites; Palygorskite; Opal; Barium; Rare earth elements.
RESUMO:Arenitos paleozóicos da Bacia do Parnaíba hospedam, além de excelentes depósitos de opala, ocorrências de calcedônias, ainda não investigadas, com potencial para o artesanato mineral e ornamental, e que poderão auxiliar o entendimento da evolução geológica da bacia. Trabalhos de campo, análises microtexturais, difração de raios-X e microscopia eletrônica de varredura com espectrometria de energia dispersiva, análises químicas e apreciaçōes gemológicas foram desenvolvidas. Destacaram-se quatro modos distintos de calcedônias, que são realçados pela riqueza em dendritos de Fe e $\mathrm{Mn}$, envolvendo núcleos opalinos, com microcavidades formadas por quartzo microcristalino, nontronita e paligorsquita. As características mesoscópicas dessas calcedônias, como textura, cor e inclusóes de dendritos, e a lapidação em cabochão e formas livres mostram potencialidade para uso no artesanato mineral e semi-joias. Como esperado, são dominadas por $\mathrm{SiO}_{2}$, com teores de $\mathrm{Al}_{2} \mathrm{O}_{3}, \mathrm{Fe}_{2} \mathrm{O}_{3}, \mathrm{MgO}$ e $\mathrm{TiO}_{2}$ baixos e muito variáveis. Entre os elementos-traço destacam-se os teores de Ba, que em geral ocorre como barita, que parece constituir uma assinatura geoquímica dos sedimentos portadores de calcedônia e opalas na bacia do Parnaíba. Essas calcedônias se formaram durante a solubilização parcial da $\mathrm{SiO}_{2}$ dos arenitos promovida por ocasiäo das deformaçöes dos arenitos em zonas de falhas e fraturas.

PALAVRAS-CHAVE: Dendritos de manganês; Paligorsquita; Opala; Bário; Elementos de terras-raras.

${ }^{1}$ Institute of Geosciences, Universidade Federal do Pará, Belém (PA), Brazil. E-mail: marcondeslc@gmail.com 2Postgraduate Program in Geology and Geochemistry, Institute of Geosciences, Universidade Federal do Pará, Belém (PA), Brazil. E-mail: quezialencar@yahoo.com.br 3Instituto Federal de Educação, Ciência e Tecnologia do Piauí - IFPI, Teresina (PI),Brazil. E-mail: prof.erico66@gmail.com, sarisekamanda@gmail.com ${ }^{4}$ Geólogo autônomo, Universidade Federal do Pará, Belém (PA), Brazil. E-mail: henrique_dfa@yahoo.com.br *Corresponding author.

Manuscript ID: 20160006. Received in: 01/12/2016. Approved in: 07/28/2016. 


\section{INTRODUCTION}

The micro to cryptocrystalline varieties of quartz known as chalcedony and agate are appreciated since the dawn of humanity. The oldest records are in the Old Testament books of the Bible and the Book of Revelation. The chalcedony expression has Greek origin and refers to the ancient city of Chalcedonian (Chalkedon) in Asia Minor, which is now the eastern part of Istanbul.

Chalcedony and small agate deposits are found almost worldwide; however, the most significant ones are found in Germany, in the USA, and in Brazil. In Brazil, the chalcedonies and agates most appreciated are those of the municipalities of Soledade, Salto do Jacuí, Iraí, Ametista do Sul, and Frederico Westphalen from Rio Grande do Sul, in the agates form (Mossman \& Juchem 2000; Pöllmann et al. 2002). They also occur in Minas Gerais, Bahia, and Goiás. The occurrence of Calçadinha Farm situated in Nazareth do Piauí municipality, state of Piauí (Fig. 1), was recently discovered during geological mapping performed by Erico Rodrigues Gomes. It occupies a strip of land of at least $1000 \mathrm{~m}$ long and $300 \mathrm{~m}$ wide, NE-E/SW-W, and are housed in the sandstones and siltstones of the Poti Formation (the Parnaíba Basin), intensely fractured and breached. The Poti Formation rests on the Longá Formation and is consisted of shale, siltstone, and limestone, and both are Devonian/Carboniferous in age. The Poti Formation is then overlain by the Cretaceous Corda Formation, with same lithological constitution of the underlying formations. In addition to these units in Calçadinha region, colluvial-alluvial deposits (sand, clay, gravel, and ferruginous lateritic concretions) were mapped, as young covers (Schobbenhaus et al. 2004).

The present study encompasses the geological, textural, mineralogical, and chemical aspects of chalcedonies in Calçadinha, and aims at showing their importance both for the gemology and for the mineral craft, in addition to discussing their origin and potential for new deposits in the region.

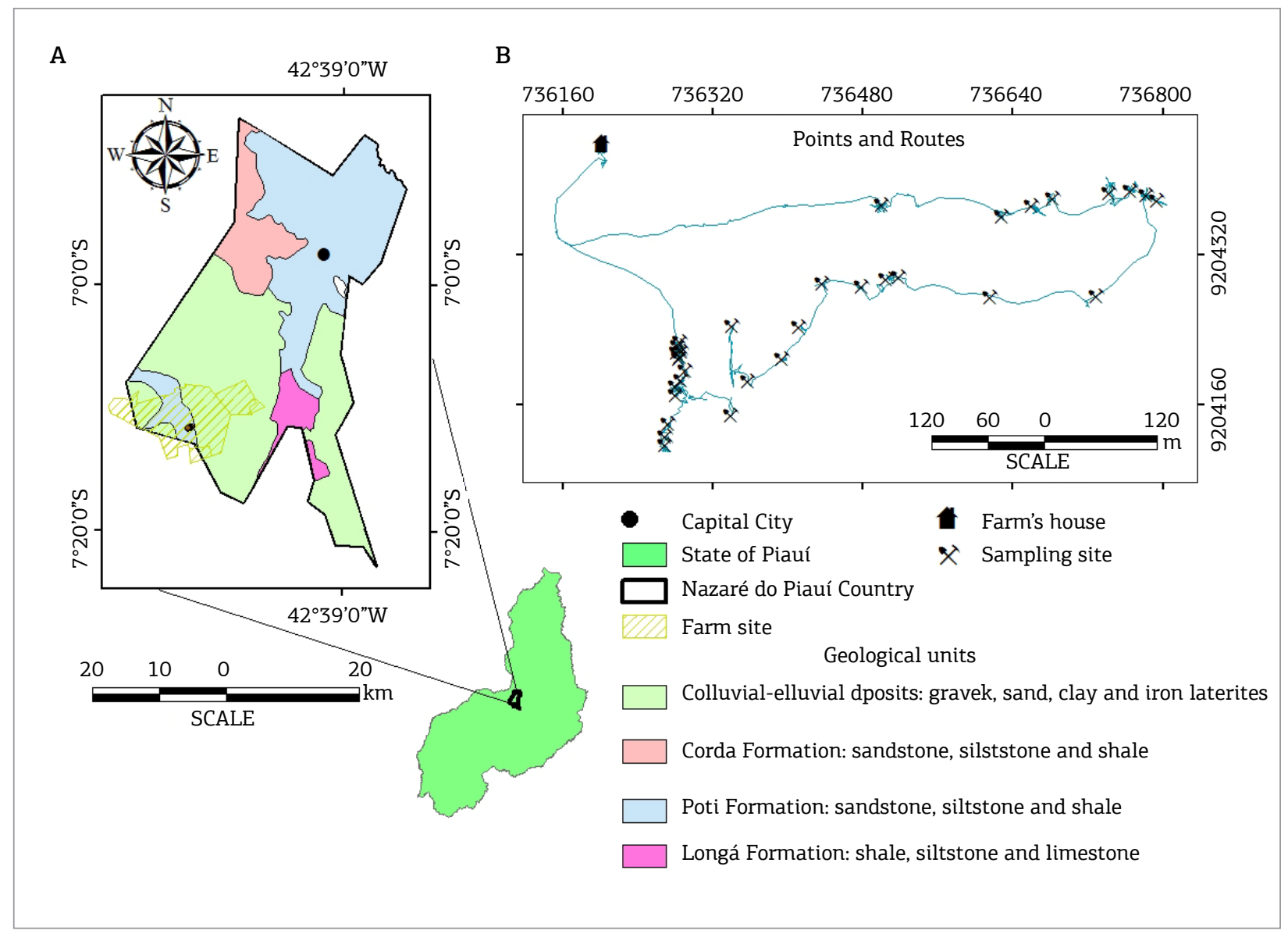

Figure 1.(A) Lithological sketch map for the region of Calçadinha farm (extracted from Schobbenhaus et al, 2004) and (B) a sampling map with collecting points of chalcedony. 


\section{MATERIALS AND METHODS}

\section{Geological Survey and Sample Collection}

Geological survey of deposit area was supported by GPS and free images of Google Earth. In parallel, samples of varieties of chalcedony and associated materials or country rocks were collected, according to the previous field work performed by the Geologist Erico Gomes. At that moment, 32 outcrops were described, and 49 samples were collected (Fig. 1). Additionally, 30 polished stones, which were prepared during a lapidary training course held in Calçadinha farm, were available.

\section{Laboratory analysis and data treatment}

Initially, all samples were imaged with high-resolution digital camera and associated images were stored. Then they were described using a stereomicroscope, with up to $60 \mathrm{X}$ increase and in this opportunity, were also imaged and archived. Based on these descriptions and images, samples were selected for mineralogical analysis by X-ray diffraction (XRD), optical and electron microscopy, and bulk chemical analysis, covering different varieties of chalcedony.

For optical transmission microscopy, polished thin sections were prepared and for assessment of gemological characteristics, the collection of polished forms mentioned above was used. Additional polished sections were also prepared for the same purpose. To perform the mineralogical analysis by XRD and bulk chemistry, a portion of each selected sample was pulverized to $<200$ mesh. Millimetric large fragments of some samples were used for analysis by scanning electron microscopy with energy dispersive spectrometry (SEM/EDS). All these activities were carried out in the laboratories of the Institute of Geosciences, except the total chemical analysis, performed at Acme Ltd, Vancouver, Canada.

The analyses by optical microscopy were performed on Carl Zeiss optical microscope and stereomicroscope also from Carl Zeiss. XRD analyses were performed with a PANalytical diffractometer, model X'PERT PRO MPD (PW 3040/60) with a goniometer PW 3050/60 (theta-theta) equipped with a copper anode $(\lambda \mathrm{Cu} \mathrm{Ka}=1.5406 \AA)$ able to be operated in $40 \mathrm{kV}$ and $35 \mathrm{~mA}$, detector RTMS type, $\mathrm{X}$ 'Celerator. The software used for data acquisition was the X'Pert Data Collector, version 2.1a, and the data processing used the X'Pert HighScore software version 2.1b, of PANalytical.

The SEM/EDS analyses were performed with the electron microscope model Scan LEO-1430. The images were generated under electron beam of $90 \mu \AA$, constant acceleration voltage of $10 \mathrm{kV}$, and working distance of $15 \mathrm{~mm}$. For this purpose, it was also used the SEM/EDS bench Hitachi, at low vacuum. The analyses by infrared spectroscopy (Fourier transform infrared) were performed with a Bruker Vertex 70/80 equipment.

For total chemical analysis (major, minor, and traces), the samples were initially fused with the aid of lithium metaborate and tetraborate, and the resulting glass dissolved with nitric acid. The determinations of the chemical elements were made by ICP-OES and ICP-MS in nine representative samples of the main textural varieties of chalcedony. The treatment of analytical results was supported by Statistica and Excel softwares.

\section{RESULTS AND DISCUSSION}

\section{Occurrences, Varieties, and Mineralogical Constitution}

The chalcedonies occur as of metric pockets embedded or in fault zones in sandstones and siltstones of the Poti Formation with outcrop area reaching 1000 per $300 \mathrm{~m}$. Four predominant varieties were identified after the texture, structure, and main color (Fig. 2 and 3):

1. Greenish gray compact chalcedony, self fracturable when dehydrated;

2. Compact and cohesive chalcedony, in shades of gray to cream;

3. Compact and cohesive chalcedony with rosy sandstone relicts, silicified (partially turned in chalcedony), or brecciated chalcedony;

4. Chalcedony with fragments and/or red sandstone cores.

The chalcedonies self-fracturable are restricted in occurrence and rich in Mn oxyhydroxide dendrites with milky white opal portions. Since the compact gray chalcedonies vary after the aspect with gaps to solid, wherein the "fragments" suggests the inheritance siltstone and sandstones strongly silicified, or replaced by chalcedony (Fig. 3 and 4) or milky quartz (Fig. 2B and 2D). Quartz cores are bordered by milky opal (Fig. 2B). The Mn oxyhydroxides dendrites are common (Fig. 2), whereas the Fe oxyhydroxides, although rare, are more developed. The dominant mineral of these chalcedonies is, of course, quartz, with opal (A, CT, and T) restricted according to XRD data (Fig. 3), which to some extent explains its tendency to dehydration when exposed to low humidity ambient (dehydration).

The gray compact chalcedonies with red sandstone silicified relicts demonstrate the clear sandstone 
heritage. Milky white chalcedony involves subrounded relicts (reaction edges) of this silicified rock, that is, were invaded by chalcedony (Fig. 2A and 2B), giving the aspect cohesive gap, compact. Quartz is dominant both in the matrix and in the sandstone silicified relicts (Fig. 2 D) and its red color is provided by the Fe oxyhydroxides manifested as maghemite and/or hematite (Fig. 2C).

The chalcedonies with fragments or sandstone and/or siltstone cores, partially silicified, porous, and crumbly, are brittle and porous. A green microcrystalline mineral becomes frequent, which fulfills both various cavities as in these chalcedonies as in the solid gray, probably palygorskite according to XRD (PT-03 and PT-09 samples, Fig. 3). Submillimetric quartz crystals also fulfill small pits (1 to $2 \mathrm{~mm} ø$ ), especially in compact gray chalcedonies.

The most suitable chalcedonies for lapidary purpose are compact gray chalcedonies or red with relicts of sandstones strongly silicified (Fig. 4) that when carrying Mn dendrites, are also attractive (Fig. 4).

\section{Mineralogical Manifestations}

\section{The dendrites of Mn oxyhydroxides (simply referred to Mn dendrites)}

Manganese dendrites are striking features of beautification on Calçadinha chalcedonies; no Mn mineral was, however, identified by XRD. Analyses of SEM/ EDS suggest cryptomelane, owing to significant presence of $\mathrm{K}$ in addition of $\mathrm{Mn}$ (Fig. 5). The dendrites are designed by microscopic hemi-spherulitic subaciculares aggregates (Fig. 6); sometimes these hemi-spherulitic concentrate around quartz relict grains (Fig. 6G and $6 \mathrm{H})$.

\section{Dendrites of Fe oxi-hydroxides (Fe dendrites)}

They are less frequent than Mn dendrites, but when present they occupy proportionately larger areas, and are also, in general, associated (Fig. 6A-F) to green minerals. Because of the colloform feature, brown staining was admitted as goethite.
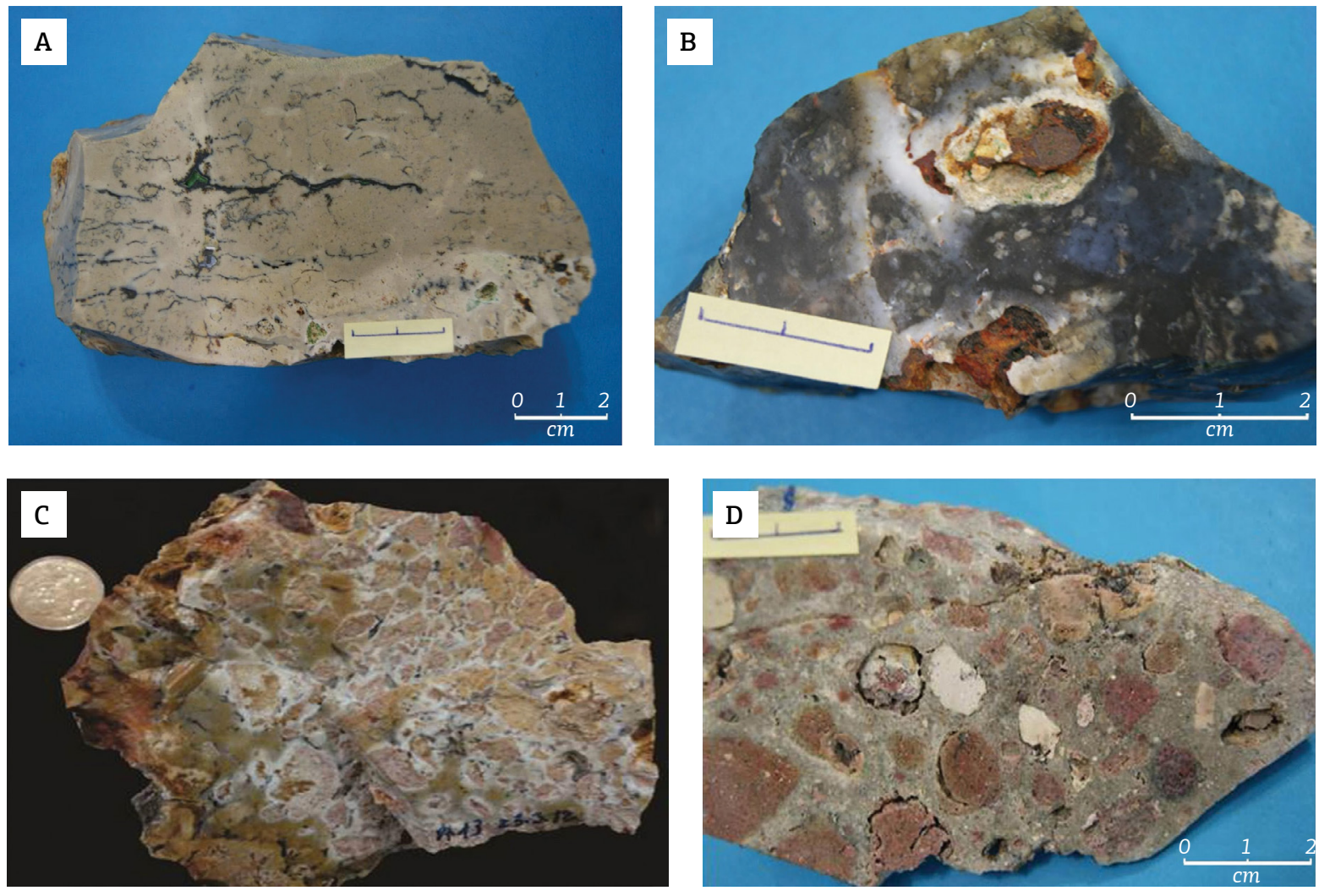

Figure 2. Hand samples images of chalcedonies Calçadinha (A and B) type cohesive compact and in different shades of gray beige. Dark tones represent Mn oxyhydroxide expressions or dendrites (A); (C) cohesive compact type with relicts of silicified rosy sandstones; (D) with sandstones fragments. 


\section{Opal}

Opal is mesoscopic and frequent in Calçadinha chalcedonies, and lends them a certain beauty, whether as a core mass of chalcedony or bypassing quartz grains or relicts of silicified sandstones (Fig. 7). As demonstrated earlier, opal varies from opal-A, opal-CT, and opal-T (Fig. 3).

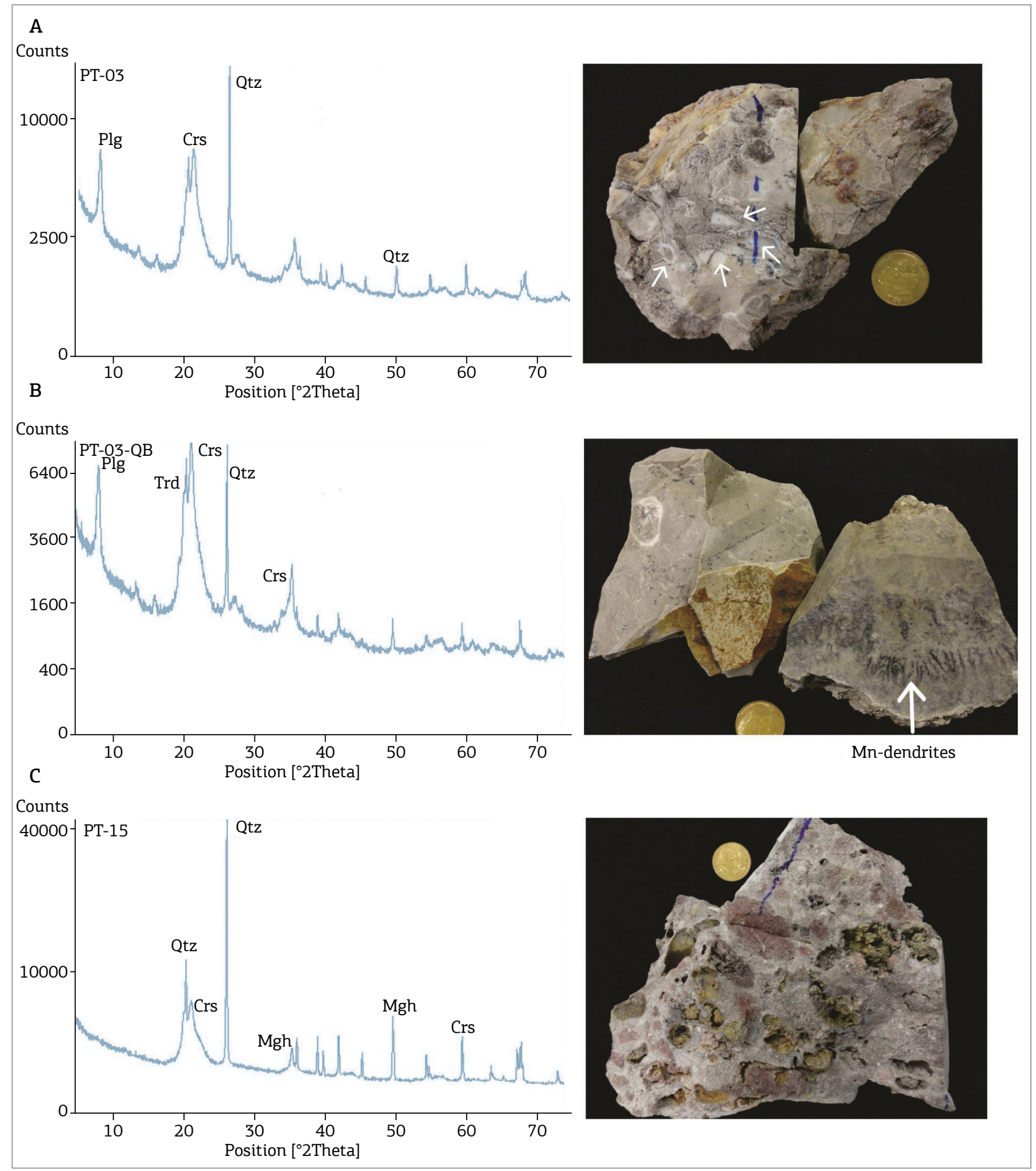

Figure 3. XRD patterns of representative samples of Calçadinha chalcedony. (A) Sample PT-03: rich in milky white opal portions (cristobalite and tridymite) indicated by arrows; (B) Sample PT_09QB, primarily comprising tridymite, cristobalite, and quartz and dendrites of Mn oxyhydroxides; (C) PT-15 sample: chalcedony with relicts of silicified red sandstone (in red) dominated by quartz and cristobalite (white matrix) and maghemite with yet. Qtz: quartz; Crs: cristobalite; Trd: tridymite; Mgh: maghemite; Plg: palygorskite. Please observe in image A the white opal manifestations, and in image B dendrites of Mn oxyhydroxides (indicated by arrow). The majority of the minerals were identified only by XRD. 


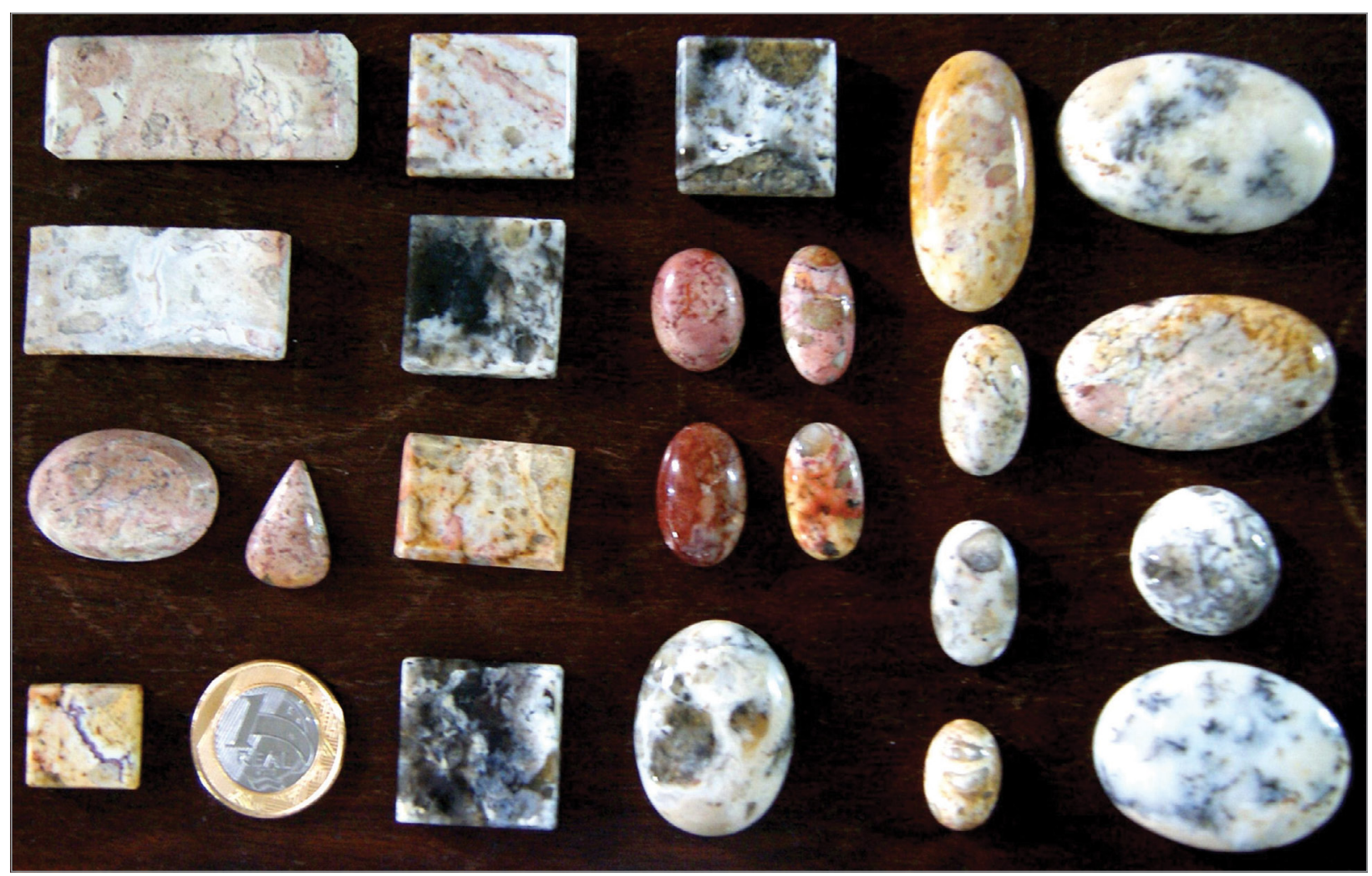

Figure 4. Different cut forms (cabochon, square, and rectangular) initially applied to Calçadinha chalcedonies. Edge of the largest square is $2.7 \mathrm{~cm}$.

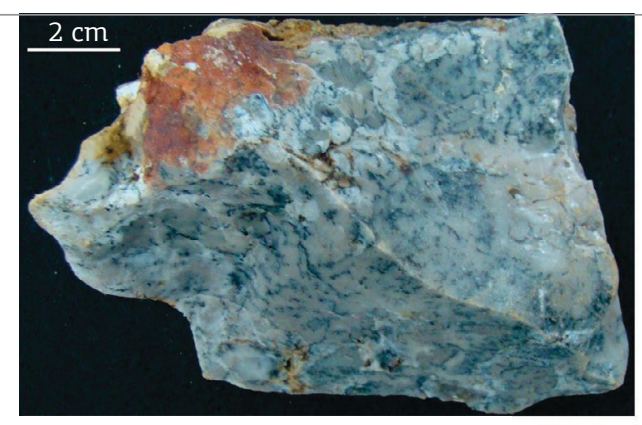

Hand sample:

Calcedon with Mn Dendrites.

\begin{tabular}{c|c}
\hline \multicolumn{2}{c}{1 - Mn Dendrites } \\
\hline Element & Concentration \\
\hline $\mathrm{O}$ & 28.3 wt.\% \\
\hline $\mathrm{Al}$ & 0.61 wt.\% \\
\hline $\mathrm{Si}$ & 25.3 wt.\% \\
\hline $\mathrm{K}$ & 0.8 wt. $\%$ \\
\hline $\mathrm{Ti}$ & 3.6 wt. $\%$ \\
\hline $\mathrm{Mn}$ & 41.3 wt. $\%$ \\
\hline & 100 wt. $\%$ \\
\hline
\end{tabular}

\begin{tabular}{c|c}
\hline \multicolumn{2}{|c}{ 4 - Chalcedon Matrix } \\
\hline Element & Concentration \\
\hline $\mathrm{O}$ & 50.8 wt.\% \\
\hline $\mathrm{Si}$ & $49.1 \mathrm{wt} . \%$ \\
\hline & 100 wt.\% \\
\hline
\end{tabular}

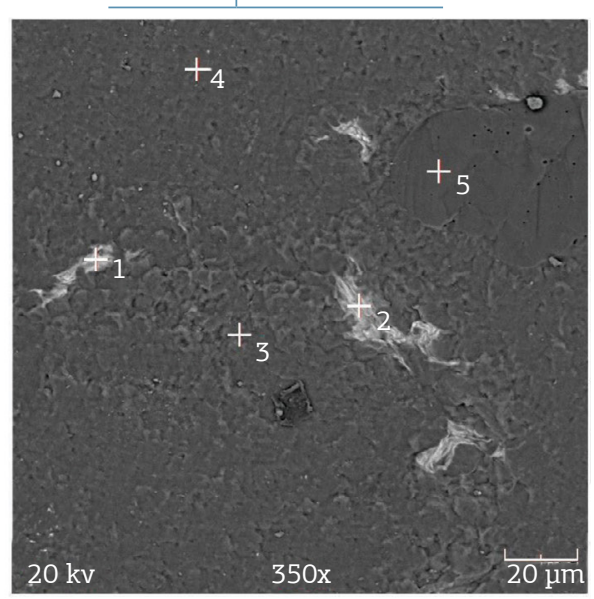

\begin{tabular}{c|c}
\hline \multicolumn{2}{c}{ 5 - Quartz Grain } \\
\hline Element & Concentration \\
\hline O & 45.7 wt.\% \\
\hline $\mathrm{Si}$ & 54.3 wt.\% \\
\hline & 100 wt.\% \\
\hline
\end{tabular}

2 - Mn dendrites
Element Concentration

\begin{tabular}{|c|c|}
\hline 0 & 32.6 wt.\% \\
\hline $\mathrm{Al}$ & 0.8 wt.\% \\
\hline $\mathrm{Si}$ & 18.8 wt. $\%$ \\
\hline $\mathrm{K}$ & 0.9 wt.\% \\
\hline $\mathrm{Ti}$ & 3.6 wt.\% \\
\hline \multirow[t]{2}{*}{$\mathrm{Mn}$} & 43.2 wt. $\%$ \\
\hline & 100 wt.\% \\
\hline
\end{tabular}

3 - Chalcedon Matrix Element Concentration

\begin{tabular}{c|c}
\hline $\mathrm{O}$ & 45.2 wt.\% \\
\hline $\mathrm{Mg}$ & 1.6 wt.\% \\
\hline $\mathrm{Al}$ & 1.9 wt.\% \\
\hline $\mathrm{Si}$ & 52.2 wt.\% \\
\hline & 100 wt.\% \\
\hline
\end{tabular}

Figure 5. Scanning Electron Microscopy (SEM) image and semiquantitative chemical analysis (EDS) in areas of Mn dendrite domains (analysis of items 1 and 2), of relicts of quartz grains (analysis of item 5), and of cryptocrystalline quartz matrix (analysis of items 3 and 4) in the gray compact chalcedony with mesoscopic Mn dendrites (in black). 

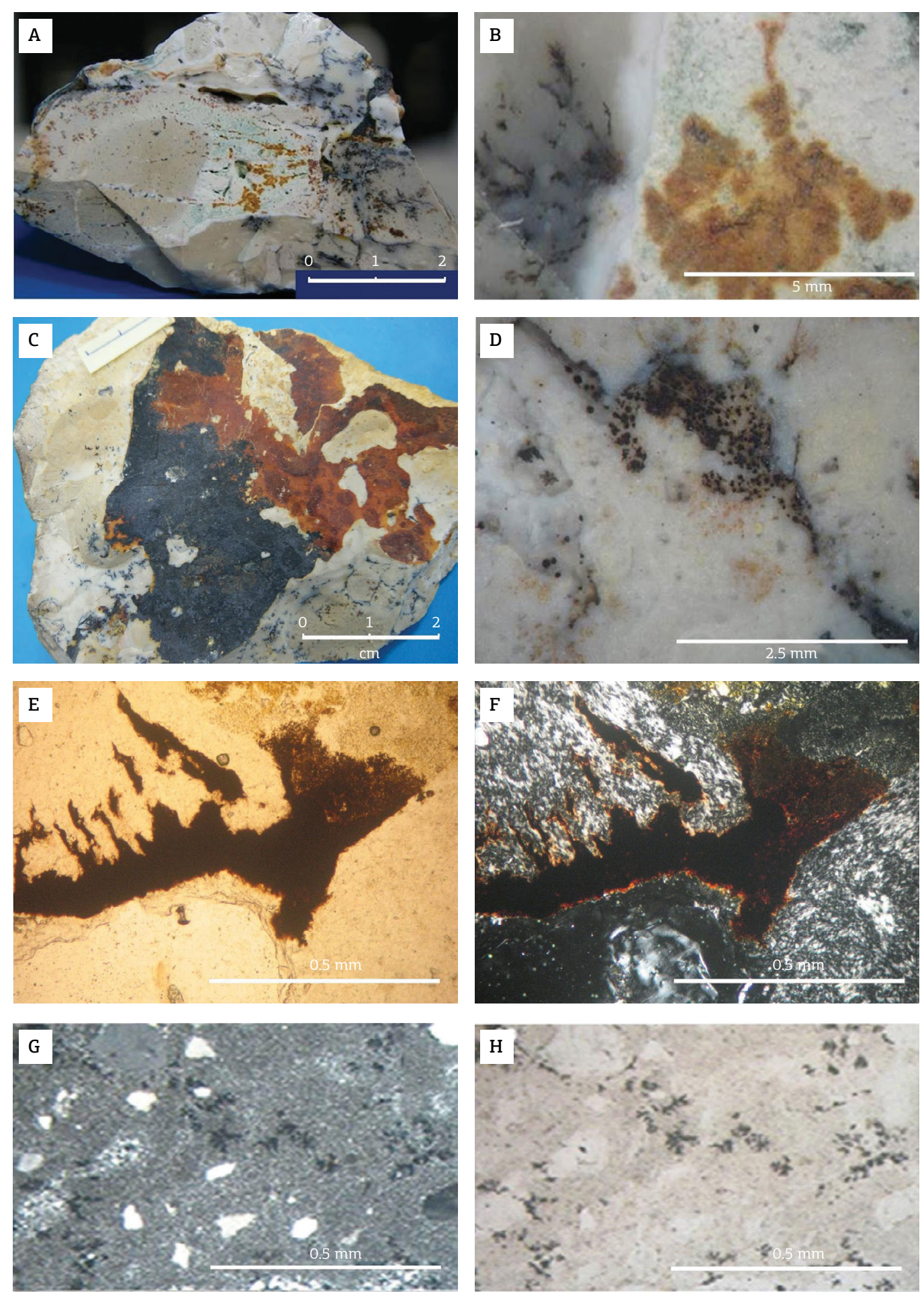

Figure 6. (A and B) Fe oxyhydroxides (brown) dendrites associated with Mn ones (black) and green mineral (palygorskite). In Figure B, a detail of A, the Fe dendrites (brown area) are in the porous chalcedony matrix with green mineral and Mn dendrites in massive chalcedony, separated by a domain of milky white opal; (C) Fracture surface covered with film of Mn oxyhydroxides (black) and Fe (brown), and microdendrites of Mn oxyhydroxides; (D) Micro-spherulites of Mn oxyhydroxides describe the dendritic formations, which appear to occupy cracks and growth sutures; (E and F) Fe oxyhydroxide film (goethite) is spread along fissure, respectively, in natural light and cross nicols; ( $\mathrm{G}$ and $\mathrm{H}$ ) Mn dendrites (cryptomelane) distributed in mass of chalcedony cementing quartz grains, respectively, crossed nicols and natural light. 

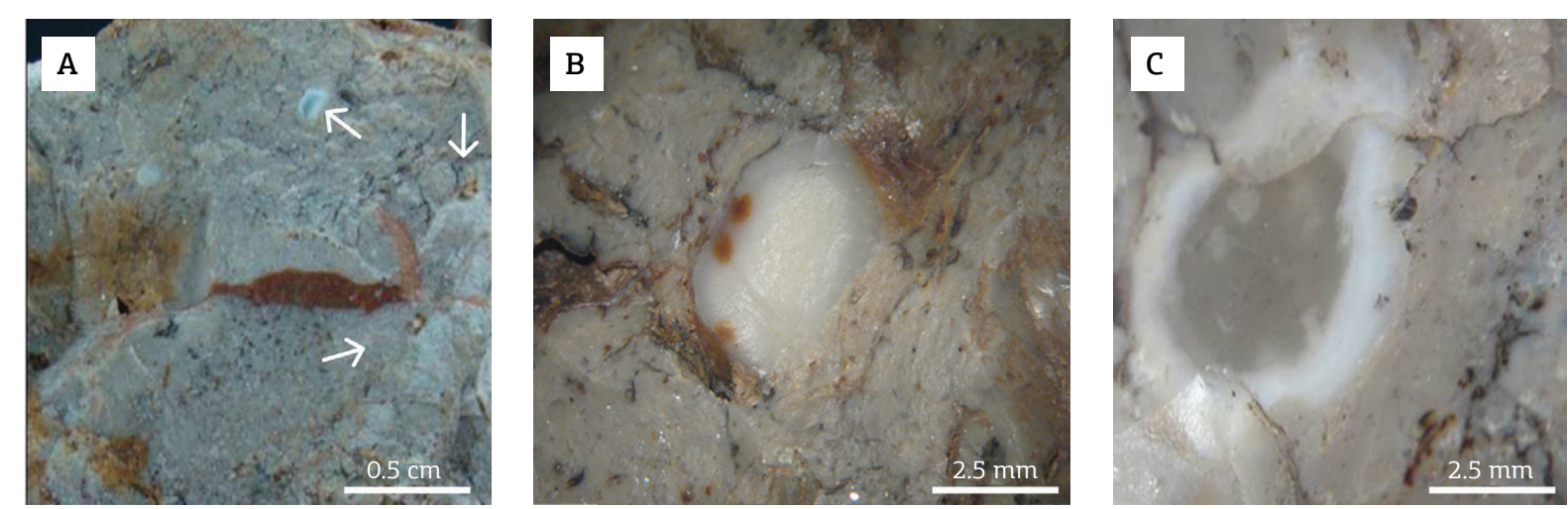

Figure 7. Opal manifestations in Calçadinha chalcedonies in domain of $\mathrm{Mn}$ and Fe dendrites. (A) Hand sample with opal pale bluish features (indicated by arrows); (B) Milky opal with Fe oxyhydroxide spots (brown) on chalcedony matrix derived of "sandstone"; (C) Milky-white opal surrounding transparent core of chalcedony, in chalcedony matrix with $\mathrm{Mn}$ and Fe dendrites.

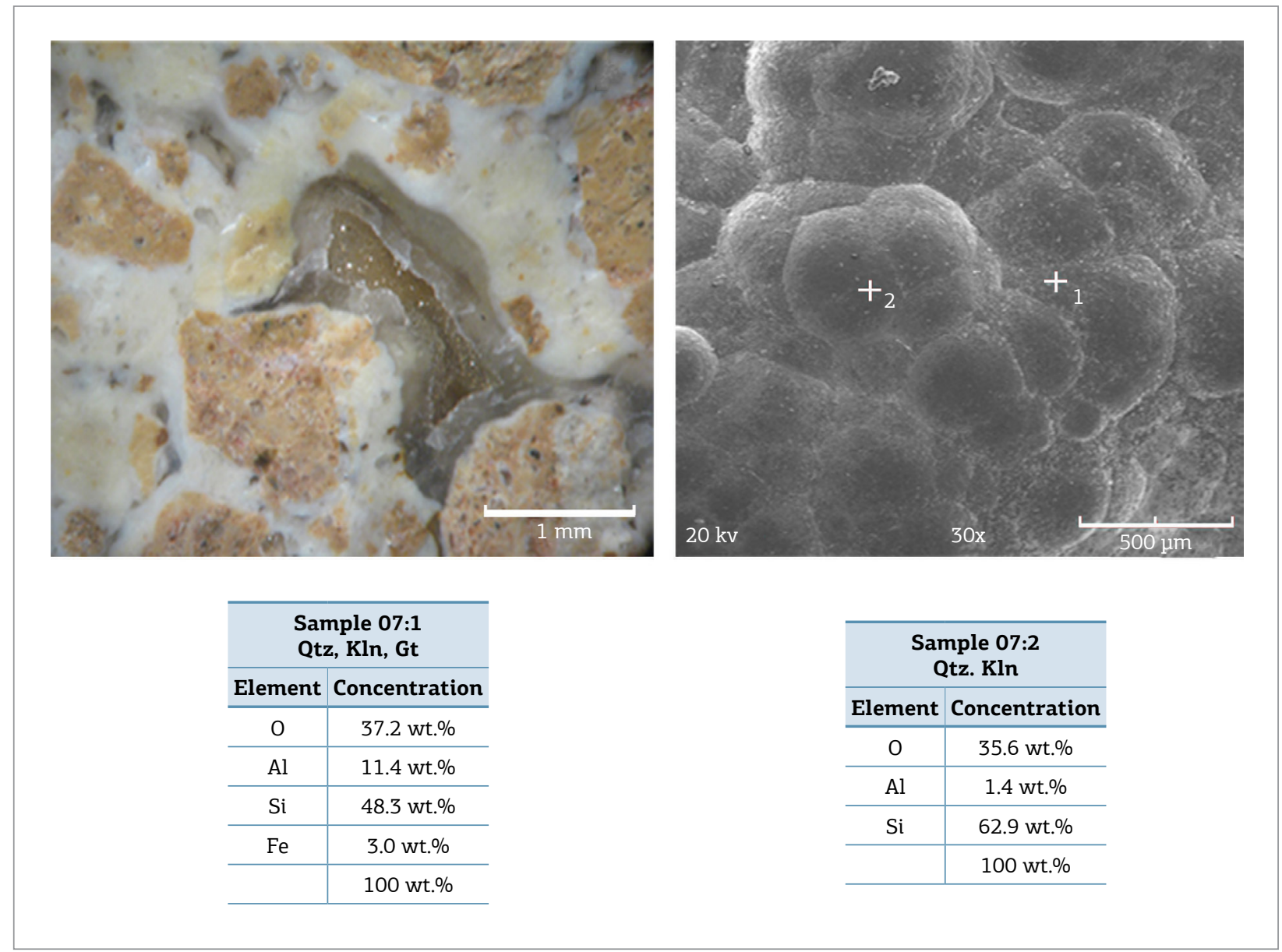

Figure 8. Micro druse of quartz in Calçadinha chalcedonies. (A) Quartz micro druse in chalcedony-opal matrix surrounding relicts of siltstone from beige to brown; (B) SEM images and EDS semiquantitative chemical analysis of a microbotrioidal surface located in the cavity, consisting mainly of $\mathrm{Si}$ and $\mathrm{O}$, with less $\mathrm{Al}$ and (Fe), suggesting that this is constituted of chalcedony (quartz), kaolinite, and (goethite) to a lesser extent. 


\section{Micro druse of quartz}

Quartz crystals manifest themselves only in the millimeter to subcentimeters druse (micro druse of quartz) or cover botryoidal surfaces of same magnitude along fractures and cavities (Fig. 8). Quartz also occurs in grain size as the main component of sand and silt grains of sandstones and siltstone relicts, and therefore is inherited.

\section{Smectite (nontronite) and/or palygorskite}

Light green cryptocrystalline mineral occupies microcavities (Fig. 9) generally covering walls of microcrystalline quartz. In some of these, $\mathrm{Mn}$ dendrites and part in Fe orthogonally converge to chalcedony bands. This green material was related to the smectite, possibly nontronite type, or palygorskite, which was identified by XRD (Fig. 3).

\section{Cryptocrystalline quartz}

\section{(chalcedony) and associated minerals}

The Calçadinha chalcedonies are represented in manifestations ascribed by parallel plans or irregular, fibrous, needle-like, radial constituting semi-spherical, hemi-spherical, and spherical formations, as well as cryptocrystalline masses (Fig. 10). This complex universe of micro to the cryptocrystalline quartz involves or even substitutes partially or fully inherited quartz grains of sandstones and siltstones, and contain opaline zones and cores and $\mathrm{Mn}$ and Fe dendritic manifestations. Common chemical reaction edges are highlighted by grain gulfs (Fig. 10A and 10B).

The platelet microcrystalline quartz stands itself perpendicular to the grain surface, developing a characteristic halo (Fig. 11A and 11B). The needle-shaped radial appears as semispherical formations that normally occupy cavities of cryptocrystalline mass (Fig. 11C-H). In contact bands, the fibrous quartz, the quartzine, rests on cryptocrystalline quartz (Fig. 11A). The largest semispherical and spherical formations are located in the core, whereas the smaller ones are on outer edge (Fig.11A, 11D and 11H). Brown manifestations of Fe oxyhydroxide needle-shaped radial are separately installed at the contact between the needle-shaped radial chalcedony zone and fibrous zone (Fig. A, B, C, G, H).

\section{Chemical composition}

The Calçadinha chalcedonies, as expected, are mainly composed of $\mathrm{SiO}_{2}, 91.0 \%$ on average, varying from 83.9 to 96.9 (Table 1). Additionally, they highlight only the $\mathrm{Al}_{2} \mathrm{O}_{3}$ content, and even if low, show great variation from 0.24 to $3.07 \%$. The same occurs with the $\mathrm{MgO}$ 0.01 to $2.56 \% ; \mathrm{Fe}_{2} \mathrm{O}_{3}$ from 0.57 to 1.99 ; and $\mathrm{TiO}_{2}$ from 0.06 to 0.47 . The other components such as $\mathrm{CaO}, \mathrm{K}_{2} \mathrm{O}$, $\mathrm{Na}_{2} \mathrm{O}, \mathrm{P}_{2} \mathrm{O}_{5}$, and $\mathrm{MnO}$ are below $0.17 \% ; \mathrm{P}_{2} \mathrm{O}_{5}$ is under the detection limit $(0.01 \%)$. The loss on ignition (LOI), between 1.72 and $7.93 \%$, averaging $5.09 \%$, shows that in fact chalcedonies vary from those with plenty of opal,

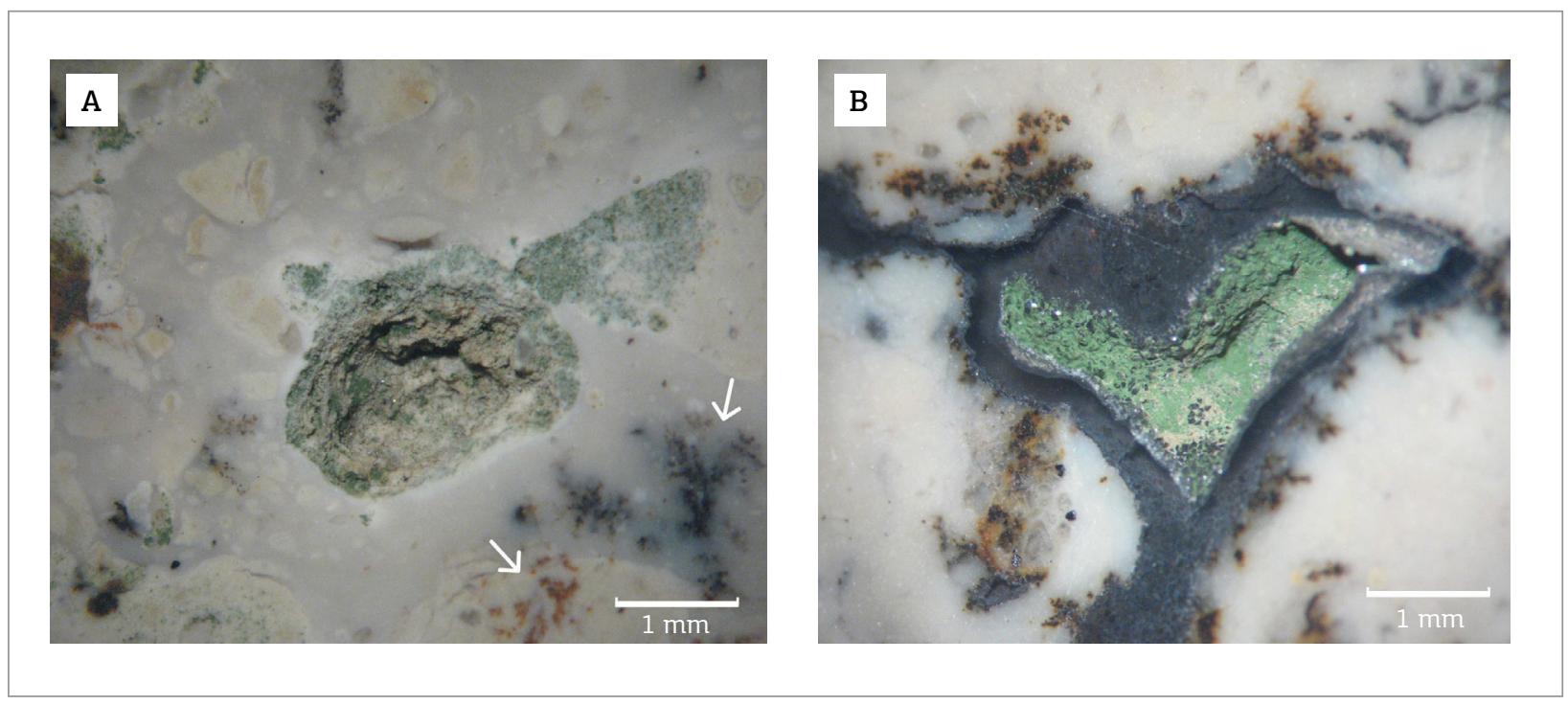

Figure 9. Green mineral manifestations. (A) Porous microgranular area in chalcedony siltstone, wherein micrograins are supported or are intergrown with green mineral, nontronite, surrounded by opal halo in chalcedony matrix. Highlighted are the Mn dendrites (black) (in chalcedony) and Fe dendrites in the relicts of siltstones (brown); (B) Microcavity inside the white chalcedony coated by quartz microcrystals, which are covered by the green nontronite, or parlygorskite. The wall is made of bands of chalcedony which converges to black chalcedony and then orthogonal Mn (black) and Fe (brown) dendrites. 

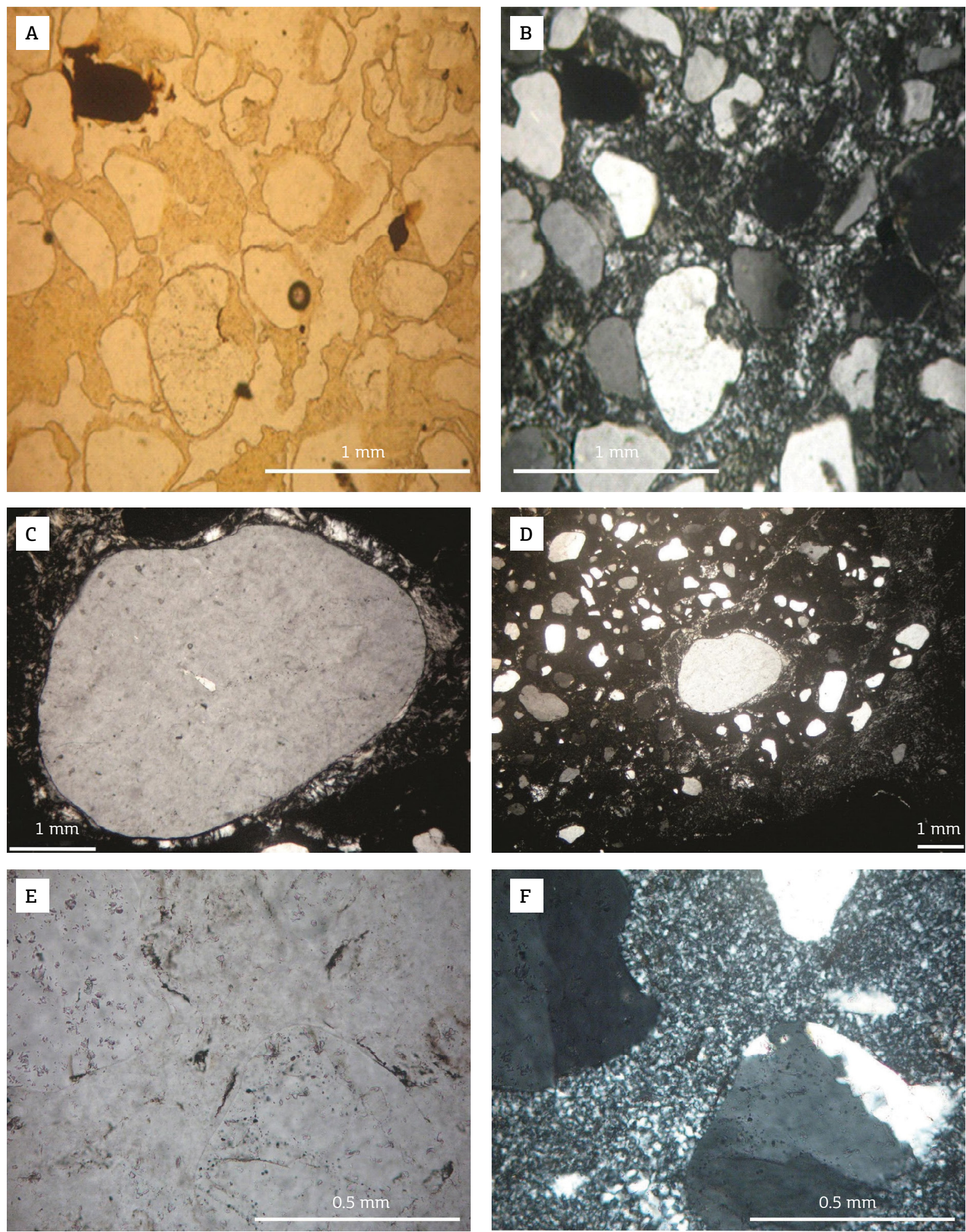

Figure 10. Chalcedony having relic granular texture of siltstone and sandstone, in which cryptocrystalline quartz (A to D) and/or quartzine (D) invade and replace part (gulf reaction) or completely monocrystalline quartz grains, besides Fe oxyhydroxide spots (in brown) (A and B). The chalcedony is formed by micro platelets or also by banded materials given by staining of Fe oxyhydroxides ( $E$ and $F$ ). Images in natural light $(B$ and $F$ ); others in crossed Nicols. 

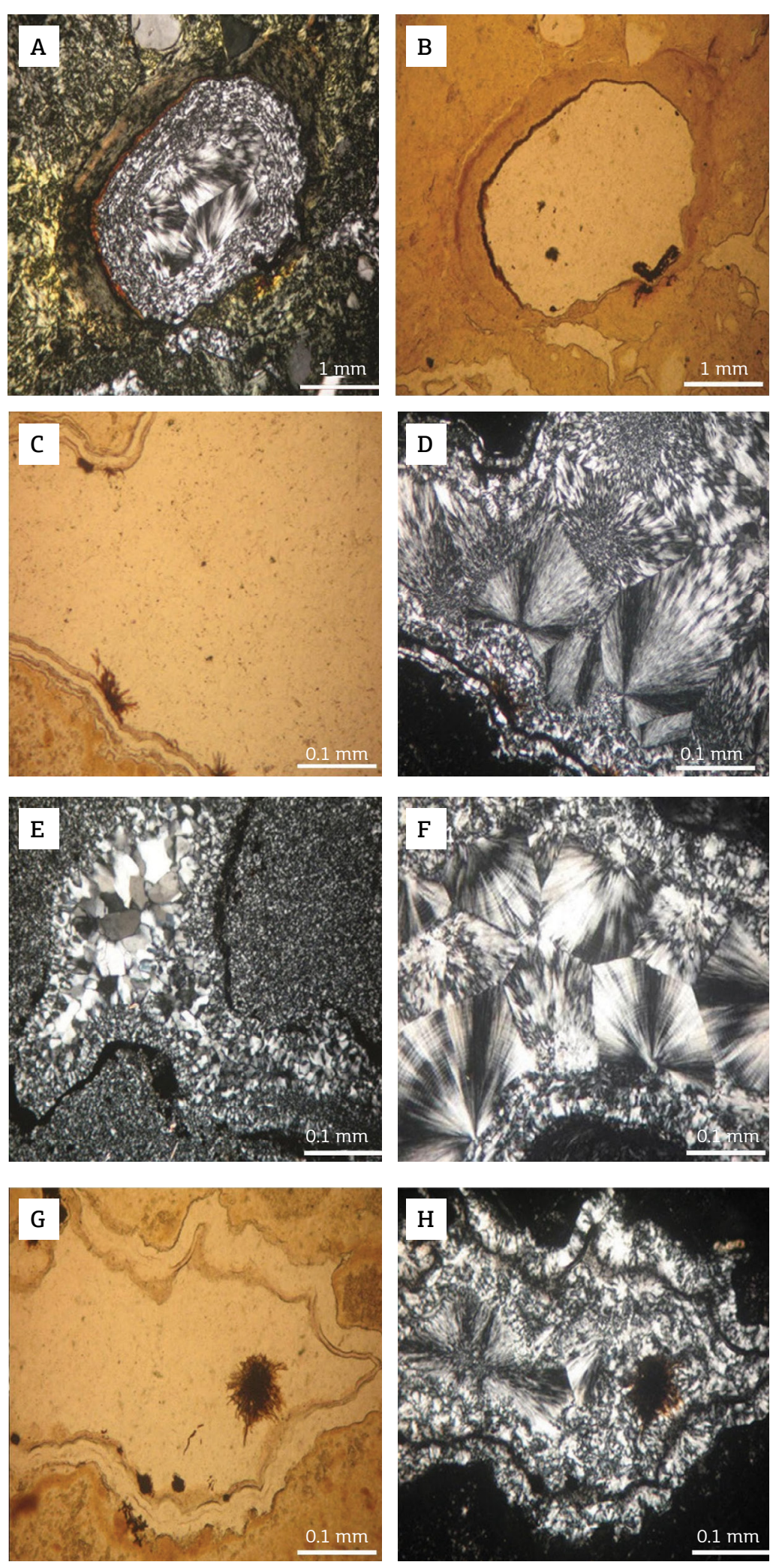

Figure 11. Possible grain (sand size) of rounded quartz replaced by cryptocrystalline quartz (chalcedony) surrounded by Fe oxyhydroxides in contact with cryptocrystalline matrix also chalcedony. Quartz is radially needle shaped in the core, from six germs, bordered by cryptocrystalline quartz in aggregate micro plaques describing concentric bands (A) crossed Nicols and (B) natural light]. This same radial needle-shaped cryptocrystalline quartz is widely observed in chalcedony matrix or filling cavities in the same, or may include needle-shaped aggregate or mass of Fe oxyhydroxides, which still have the edges ( $\mathrm{C}$ to $\mathrm{H}$ ) or become a large extent in mono-crystalline aggregates of quartz (E) on left side. 
that is, high water (LOI) to the quartz domain, represented by low values of LOI. PT-03 is the most chemically different sample from the set, with high contents of $\mathrm{Al}_{2} \mathrm{O}_{3}, \mathrm{MgO}$, in part $\mathrm{Fe}_{2} \mathrm{O}_{3}$ and $\mathrm{K}_{2} \mathrm{O}$, consequently the lower $\mathrm{SiO}_{2}$. This clearly reflects its mineral composition represented by the more expressive presence of palygorskite and nontronite. The higher $\mathrm{Fe}_{2} \mathrm{O}_{3}$ levels are interpreted as nontronite (green mineral), in part goethite (Fe dendrites) and maghemite/hematite, whereas those with more magnesium and less iron, are interpreted as palygorskite. Although Mn dendrites are typical in chalcedonies, the total levels of $\mathrm{MnO}$ are below $0.14 \%$, but within the margin of sandstones and siltstones.

Negative chemical correlations between $\mathrm{SiO}_{2}$ and $\mathrm{Al}_{2} \mathrm{O}_{3}$, $\mathrm{MgO}$ and $\mathrm{K}_{2} \mathrm{O}$, clearly indicate the antagonism between quartz and opal with palygorskite and smectite, perhaps illite, which is reinforced by the positive correlation between $\mathrm{Al}_{2} \mathrm{O}_{3}$ and $\mathrm{K}_{2} \mathrm{O}$ and $\mathrm{MgO}$ (Fig. 12).

Table 1. Chemical composition (\% by weight for major and minor elements and ppm for trace elements) of Calçadinhas chalcedonies.

\begin{tabular}{|c|c|c|c|c|c|c|c|c|c|c|c|c|c|c|c|c|c|}
\hline Analytes & $\mathrm{SiO}_{2}$ & $\mathrm{Al}_{2} \mathrm{O}_{3}$ & $\mathrm{Fe}_{2} \mathrm{O}_{3}$ & MgO & $\mathrm{CaO}$ & $\mathrm{Na}_{2} \mathrm{O}$ & $\mathrm{K}_{2} \mathrm{O}$ & $\mathrm{TiO}_{2}$ & MnO & $\mathbf{P}_{2} \mathbf{O}_{5}$ & LOI & $\mathrm{Ba}$ & $\mathrm{Be}$ & Co & Cs & Ga & Hf \\
\hline MDL & 0.1 & 0.01 & 0.01 & 0.01 & 0.01 & 0.01 & 0.01 & 0.01 & 0.01 & 0.01 & 5.11 & 1 & 1 & 0.2 & 0.1 & 0.5 & 0.1 \\
\hline PT 03 & 83.9 & 3.07 & 1.37 & 2.51 & 0.05 & 0.04 & 0.17 & 0.32 & 0.03 & $<0.01$ & 7.9 & 79 & 3 & 82.4 & 0.6 & 3.8 & 1.6 \\
\hline PT 05 & 91.7 & 1.07 & 0.57 & 0.86 & 0.03 & 0.03 & 0.07 & 0.09 & 0.04 & $<0.01$ & 5.14 & 100 & 2 & 13.5 & 0.2 & 1.3 & 0.6 \\
\hline PT 07 & 88.4 & 2.01 & 1.99 & 0.42 & 0.06 & 0.04 & 0.12 & 0.21 & 0.06 & $<0.01$ & 5.92 & 191 & $<1$ & 13.6 & 0.4 & 2.8 & 1.3 \\
\hline РT 08 & 91.6 & 1.01 & 0.81 & 0.25 & 0.04 & 0.02 & 0.09 & 0.2 & 0.06 & $<0.01$ & 5.64 & 157 & 2 & 6.6 & 0.3 & 1.3 & 0.6 \\
\hline РТ 09 & 93.4 & 0.65 & 0.35 & 0.45 & 0.04 & 0.04 & 0.07 & 0.11 & 0.02 & $<0.01$ & 4.33 & 616 & 1 & 5.6 & 0.2 & 0.8 & 0.3 \\
\hline PT 09 QB & 85.5 & 2.44 & 1.51 & 2.15 & 0.07 & 0.03 & 0.15 & 0.4 & 0.04 & 0.03 & 7.57 & 214 & 3 & 11.9 & 0.5 & 3.1 & 1.2 \\
\hline PT 13 & 93.8 & 0.52 & 1.54 & 0.09 & 0.05 & 0.02 & 0.06 & 0.22 & 0.01 & $<0.01$ & 3.92 & 119 & 2 & 3 & 0.2 & 0.8 & 0.6 \\
\hline PT 15 & 94.4 & 0.5 & 0.83 & 0.16 & 0.03 & $<0.01$ & 0.04 & 0.47 & 0.14 & 0.01 & 3.57 & 359 & 2 & 11.4 & $<0.1$ & 1 & 1.4 \\
\hline PT 20 & 96.1 & 0.24 & 0.68 & $<0.01$ & 0.01 & 0.03 & 0.03 & 0.06 & 0.09 & $<0.01$ & 1.72 & 117 & 2 & 15.6 & $<0.1$ & 0.7 & 0.2 \\
\hline Average & 91 & 1.28 & 1.07 & 0.86 & 0.04 & 0.03 & 0.09 & 0.23 & 0.05 & 0.02 & 5.09 & 217 & 2 & 18.2 & 0.3 & 1.7 & 0.9 \\
\hline Analytes & $\mathrm{Nb}$ & Nd & $\mathbf{R b}$ & $\mathrm{Sr}$ & Ta & Th & $\mathbf{U}$ & $\mathbf{V}$ & $\mathbf{Y}$ & $\mathbf{Z r}$ & $\mathrm{Au}$ & $\mathrm{Cu}$ & Mo & $\mathbf{N i}$ & $\mathrm{Pb}$ & Zn & $\Sigma$ REE \\
\hline MDL & 0.1 & 0.3 & 0.1 & 0.5 & 0.1 & 0.2 & 0.1 & 8 & 0.1 & 0.1 & 0.5 & 0.1 & 0.1 & 0.1 & 0.1 & 1 & 0.82 \\
\hline PT 03 & 6.4 & 26.8 & 14.6 & 5.2 & 1.7 & 6.9 & 4.9 & 46 & 47.3 & 58.6 & $<0.5$ & 24.8 & $<0.1$ & 50.5 & 3.6 & 93 & 133.05 \\
\hline PT 05 & 2.8 & 3.3 & 5 & 3.3 & 1.1 & 1.2 & 3.9 & 14 & 3 & 21.3 & $<0.5$ & 13.7 & 0.1 & 32.3 & 4.6 & 13 & 15.75 \\
\hline PT 07 & 3.4 & 1.8 & 10.4 & 7.6 & 0.8 & 1.7 & 5.8 & 60 & 2.5 & 41.7 & $<0.5$ & 20.7 & 0.2 & 20.9 & 11.2 & 15 & 12.74 \\
\hline PT 08 & 3 & 1.3 & 6.6 & 4.7 & 1.1 & 1.4 & 8.7 & 46 & 1.7 & 22 & $<0.5$ & 7 & $<0.1$ & 18.7 & 4.3 & 3 & 9.98 \\
\hline PT 09 & 1.2 & 0.8 & 3.6 & 3.5 & 0.4 & 0.7 & 8.1 & 39 & 1.2 & 11.5 & $<0.5$ & 4.5 & $<0.1$ & 17.3 & 1.1 & 5 & 6.71 \\
\hline PT 09 QB & 3.7 & 6.4 & 16.1 & 6.2 & 0.4 & 1.5 & 2.2 & 42 & 5.8 & 52.1 & 2.8 & 7.9 & $<0.1$ & 21.1 & 2.3 & 8 & 32.22 \\
\hline PT 13 & 2.5 & 0.6 & 3.6 & 5.8 & 0.4 & 0.7 & 5.7 & 63 & 0.9 & 27 & 1.9 & 4.7 & $<0.1$ & 17.2 & 2.4 & 4 & 3.85 \\
\hline PT 15 & 6.3 & 13.2 & 2.5 & 5.5 & 1.5 & 0.7 & 1.9 & 35 & 5 & 60.3 & $<0.5$ & 9.1 & 0.1 & 27.9 & 3.1 & 3 & 53.8 \\
\hline PT 20 & 0.7 & 1.3 & $<0.1$ & 1.4 & 0.5 & 0.4 & 5.1 & 23 & 0.6 & 6.1 & $<0.5$ & 4.5 & 0.3 & 32.3 & 5 & 2 & 10.56 \\
\hline Average & 3.3 & 6.2 & 7.8 & 4.8 & 0.9 & 1.7 & 5.1 & 41 & 7.6 & 33.4 & 2.4 & 10.8 & 0.2 & 26.5 & 4.2 & 16 & 31.16 \\
\hline
\end{tabular}

MDL: minimum detection limit. In black are indicated the highest content each element has. 
The concentrations of trace elements (Table 1) are also comparatively low, below the crustal average, and compatible with sandstones and silts. Among them only $\mathrm{Ba}, \mathrm{Cs}, \mathrm{Rb}$, Th, rare earth elements (REE), Zn, Cu, Ni, Co, Nb, Ta, Zr, and $\mathrm{Y}$ highlight, wherein $\mathrm{Ba}, \mathrm{REE}, \mathrm{Zn}, \mathrm{Cu}$, and $\mathrm{Co}$ have strong geochemical affinity to $\mathrm{Mn}$ oxyhydroxides; $\mathrm{Zn}, \mathrm{Cu}$, $\mathrm{Ni}, \mathrm{Co}$, and the REE also to palygorskite and nontronite; and $\mathrm{Rb}, \mathrm{Cs}, \mathrm{Nb}, \mathrm{Ta}, \mathrm{Zr}$, and $\mathrm{Y}$ to illite.

The concentrations of REE are very low, even below the limits of crustal average as expected due to quartz domain; however, in general terms they are compatible with the concentrations found in quartz sandstones (Roddaz et al. 2006), where resistate minerals as zircon, which is an important REE carrier, are present. Only the PT-03 sample showed high values and above the crustal average (Table 1), which stands out for its higher content of palygorskite and nontronite, so once clayey siltstones. The REE of Calçadinhas chalcedonies when normalized to Post-Archean Australian Shales (PAAS) (Fig. 13) show roughly equivalent patterns, and only differ in the order of magnitude. There has been a subtle depletion of HREE, and negative and positive anomalies of $\mathrm{Ce}$ and $\mathrm{Eu}$, respectively, are less expressive. A single sample showed strong positive anomaly of Ce (PT-20), albeit with low levels. In general, Ce-positive anomalies are associated with the presence of Mn oxyhydroxides (Braun et al. 1990), indicating oxidation atmosphere and even formation of cerianite, as indicated by thin and wide distribution of $\mathrm{Mn}$ and Fe dendrites. Therefore, the formation of Calçadinhas chalcedonies must have occurred in oxidizing hydrothermal environment and with limited mobility, as demonstrated through the textures of this mineral.

\section{CONCLUSIONS}

The Calçadinha chalcedonies are clearly associated with sandstones and siltstones of the Poti Formation, locally deformed in fault zones. The relicts of sandstones and siltstones indicate that this circumstance of silica-saturated solutions were formed from the partial and almost total dissolution of sandstones and siltstones and precipitated themselves as quartz, micro to cryptocrystalline (silicification or calcedonization) when the solutions are saturated, invading and replacing partially or totally the texture of

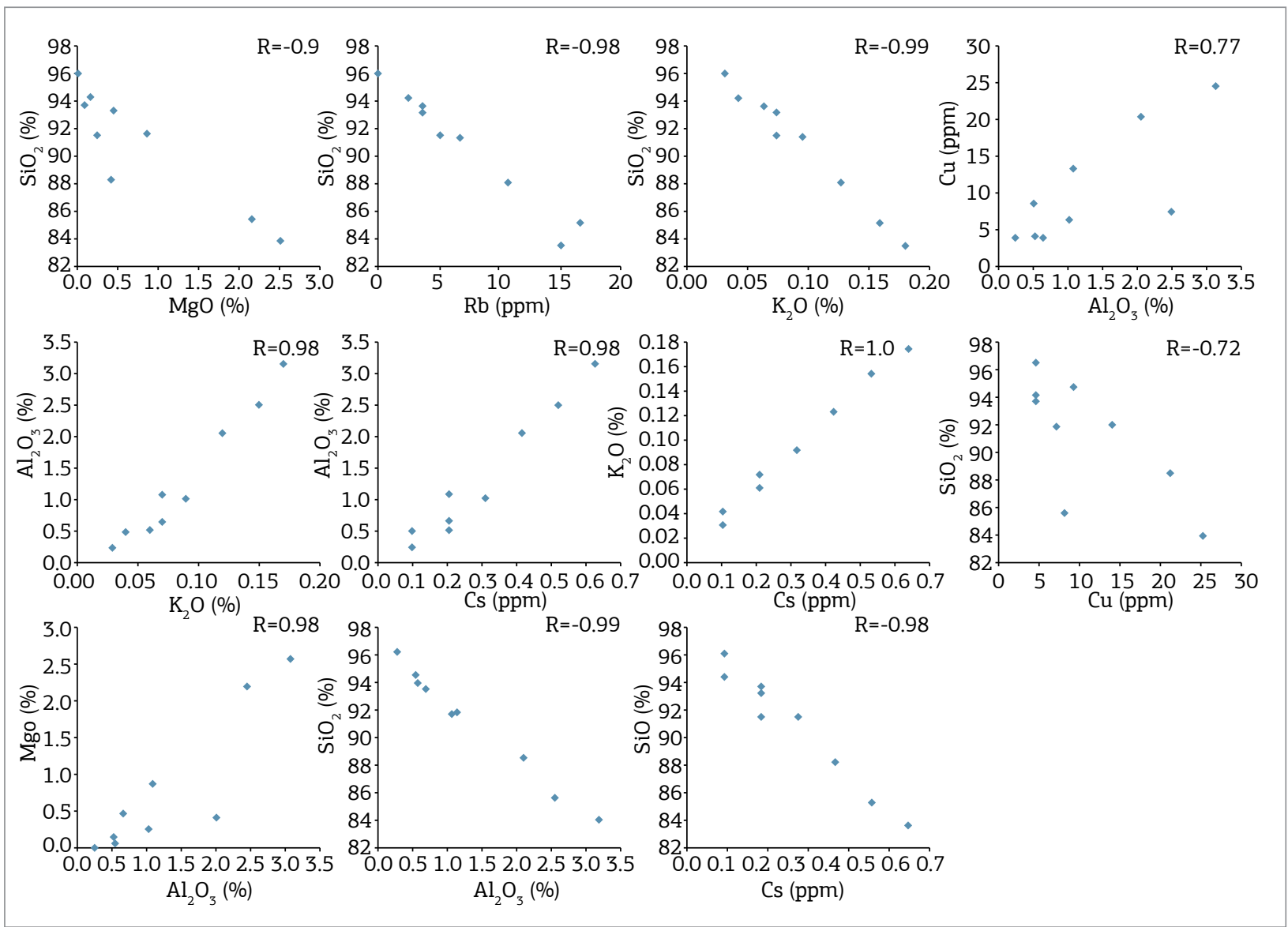

Figure 12. Binary scatter diagrams showing most significant positive and negative correlations in Calçadinha chalcedonies. 

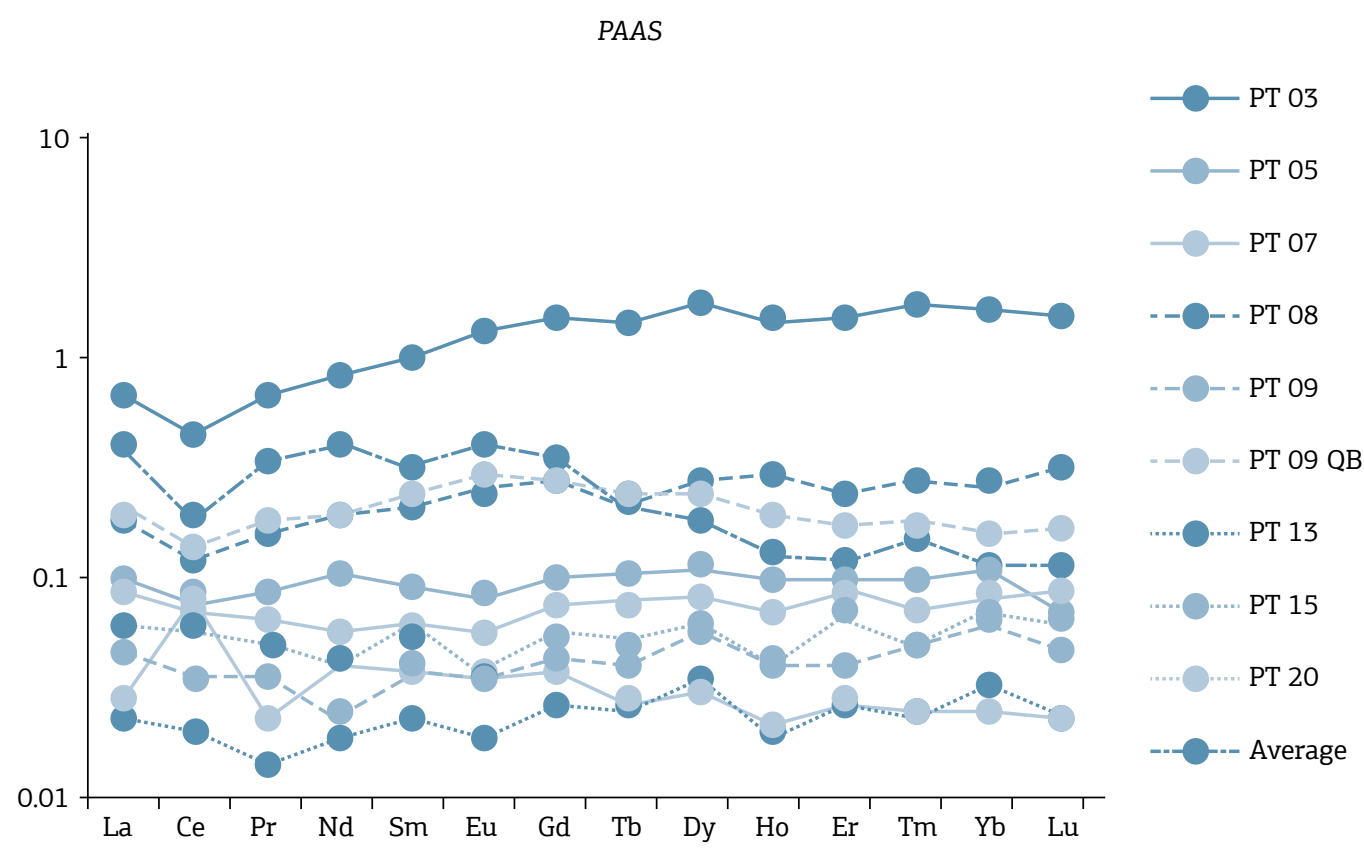

Chondrites
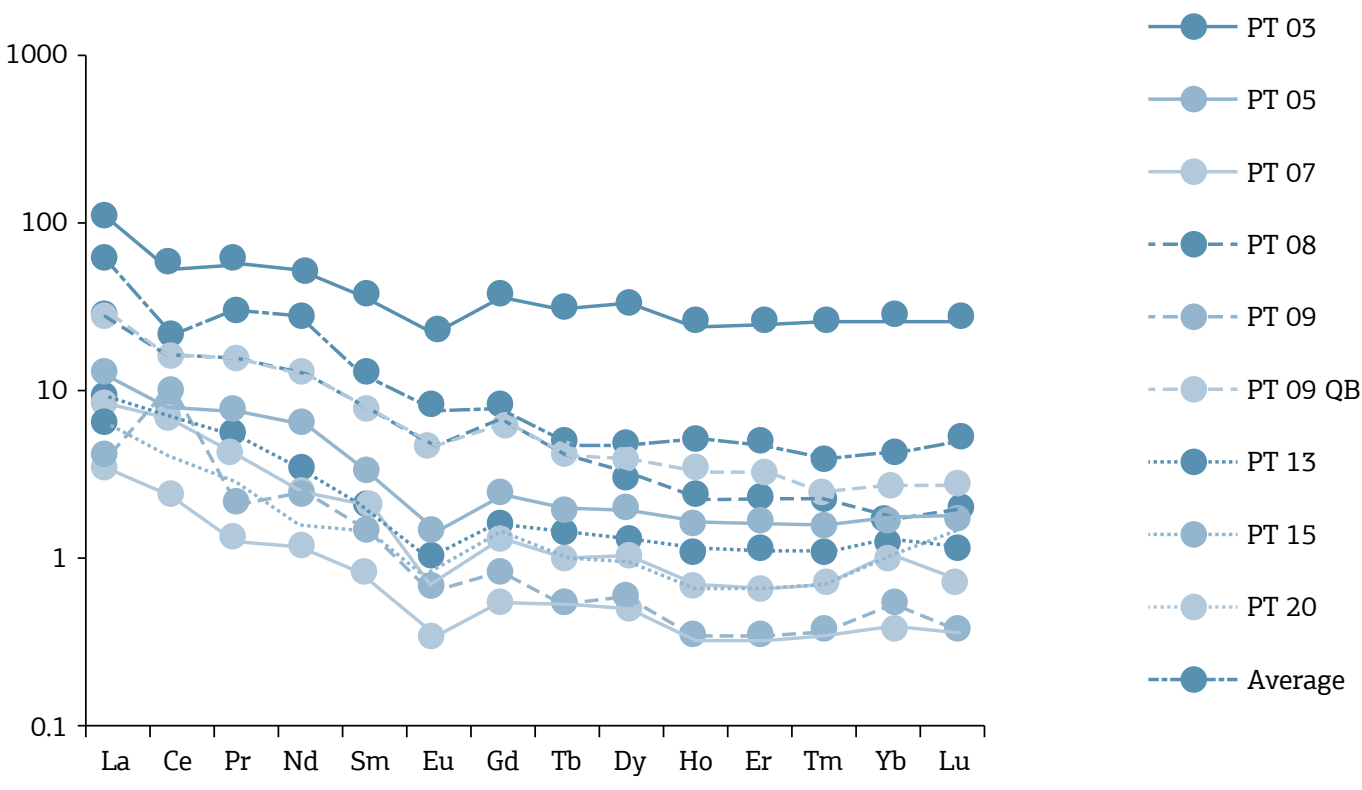

Figure 13. Distribution of the REE normalized to chondrites and PAAS. 
these rocks. Therefore, these rocks were a source of siliceous solutions and concomitantly trapped them. As these solutions were very saturated, and consequently had low mobility, they immediately precipitated chalcedony. The presence of opals indicates that the crystallization temperature was low and aqueous. Similar geological conditions were found in Buriti dos Montes (Gomes \& Costa 2007; Marques et al. 2012, 2015), where oranges opals overlapped themselves to the chalcedonies, as well partly in Pedro II, where the hot spring was also associated with diabase and basalt occurrences (Gomes \& Costa 1994; Costa et al. 2013).

The textural and mineralogical characteristics of Calçadinha chalcedonies make them interesting raw material for mineral handcrafts and/or even jewelry, where the opal features and dendrites praise its beauty, mainly when polished. However, the enclaves of friable sandstones and the self-brittle appearance are unfavorable features owing to its high moisture that is lost when exposed just to room temperature. The absence of agate pattern may be another negative aspect for this purpose.

\section{ACKNOWLEDGMENTS}

The authors acknowledge the Valdeci Cavalcante Lawyers for granting eight-month support to the Scientific Initiation scholarship modality to the undergraduate student of Geology, Quézia da Silva Alencar; LABMEV and X-ray diffraction laboratories and thin section office of the Geosciences Institute of the UFPA, for analytical support; and CNPQ for financial support and scholarships.

\section{REFERENCES}

Braun J.J., Pagel M., Muller J.P., Bilong P., Michard A., Guillerd B. 1990. Cerium anomalies in lateritic profiles. Geochimica et Cosmochimica Acta, 54(3):781-795.

Costa M.L., Gomes E.R., Pöllmann H., Angélica R.S. 2013. Opal von Pedro II/Piauí. Aufschluss, 64:49-56.

Gomes, E.R., Costa, M.L. 1994. Contribuição à gênese das opalas de Pedro II (Piauí). Geochimica Brasilensis, 8(1):79-98.

Gomes E.R., Costa M.L. 2007. Opalas do Piauí: Pedro II e Buriti dos Montes (parte II): Diamond News, 8:54-59.

Mossman D.J., Juchem P.L. 2000. Agate and amethyst of Rio Grande do Sul, Paraná Basin. Brazil. The Canandian Gemmologist, 21(4):118-126.

Marques G.T., Costa M.L., Gomes E.R. 2015. Orange opals from Buriti dos Montes, Piauí: solid inclusions as genetic guides. Rem: Revista da Escola de Minas, 68(1):53-59.
Marques G.T., Costa M.L., Gomes E.R. 2012. As fascinantes inclusões sólidas das opalas laranja de Buriti dos Montes (PI). Diamond News, 37:45-52.

Pöllmann H., Costa M.L., Wegner R. 2002. Amethyst und Achat aus S-Brasilien. Aufschluss, 53:167-180.

Roddaz M., Viers J., Brusset S., Baby P., Boucayrand C., Herail G. 2006. Controls on weathering and provenance in the Amazonian foreland basin: Insights from major and trace element geochemistry of Neogene Amazonian sediments. Chemical Geology, 226(1-2):31-65.

Schobbenhaus C., Gonçalves J.H., Santos J.O.S, Abram M.B., Leão Neto R., Matos G.M.M., Vidotti R.M., Ramos M.A.B., Jesus J.D.A. 2004. Carta Geológica do Brasil ao Milionésimo: Sistema de Informações Geográficas - Folha SB-23. Escala 1:1,000,000. Brasília, CPRM Serviço Geológico do Brasil, 41 CD-ROMs.

Available at www.sbgeo.org.br 